\title{
Effect of nuclear magnetic resonance fields in peritoneal macrophages
}

Ana Cristina Santos*, Cláudia Matos, Ana Rita Bento, Eliana Murteira, Filipe Leite, Marco Pinto, Micaela Cunha, Rosalindo Gomes, Bárbara Oliveiros, Alda Martins, Carlos Ferreira, Miguel Castelo-Branco, Vera Alves, Filipe Caseiro Alves, Manuel Santos-Rosa, Filomena Botelho

Abstract Magnetic resonance is frequently used to obtain medical images for diagnosis. To perform these exams high magnetic fields are applied, implying at least $\pm 10,000$ times the value of the Earth basal field $\left(3-7 \cdot 10^{-5} \mathrm{~T}\right)$. In our experimental study we used adherent cells (rat peritoneal macrophages), cultured in standard conditions $\left(37^{\circ} \mathrm{C}, 5 \% \mathrm{CO}_{2}\right)$ with adequate media in 6 wells plates. Three groups for each type of cell were established: control, head and body coil, being the irradiation performed with a $1.5 \mathrm{~T}$ (University Hospital of Coimbra) and a 3 T (National Functional Brain Imagiology Network - IBILI) intensity fields. Macrophages' cytotoxicity and viability were tested with the $\mathrm{MTT}^{\mathrm{i}}$ assay $0,12,36,60$ and 84 hours post-irradiation. Irradiated macrophages presented slightly less viability and adhesion features compared to control, although no differences between the head and body coil were found.

Keywords Nuclear magnetic resonance, Macrophages, Cytotoxicity.

\section{Efeitos de campos electromagnéticos em macrófagos peritoneais}

Resumo Hoje em dia os métodos complementares de diagnóstico incluem com muita frequência exames de ressonância magnética para diagnóstico médico. Para efectuar este tipo de exame são aplicados campos magnéticos de alta intensidade, pelo menos com valores \pm 10.000 superiores ao do campo basal do planeta $\left(3-7 \cdot 10^{-5} \mathrm{~T}\right)$. No nosso estudo experimental utilizámos células aderentes (macrófagos peritoneais de rato), cultivados em condições standard $\left(37^{\circ} \mathrm{C}, 5 \% \mathrm{CO}_{2}\right)$ com meios adequados em caixas de 6 poços. Estabeleceram-se três grupos de estudo para cada tipo celular: controlo, antenas de cabeça e de corpo, sendo a irradiação efectuada com duas intensidades de campo: 1,5 T (Hospital da Universidade de Coimbra) e 3 T (Rede Nacional de Imagiologia Funcional Cerebral - IBILI). Os testes de viabilidade e citotoxicidade para macrófagos foram realizados utilzando o teste colorimétrico do $M T T^{i i}$ às 0, 12, 36, 60 e 84 horas pós-irradiação. Os macrófagos irradiados apresentaram uma viabilidade ligeiramente menor e alterações de aderência em comparação com o controlo, embora não haja diferenças estatisticamente significativas entre os exames com antenas de cabeça e de corpo.

Palavras-chave Ressonância magnética nuclear, Macrófagos, Citotoxicidade.

\footnotetext{
*e-mail: cristina@ibili.uc.pt

Recebido: 03/02/2010 / Aceito: 18/07/2010

i 3-(4,5-dimethilthyazol-2-yl)-2,5-diphenyl tetrazolium bromide

ii Brometo de 3-(4,5-dimetiltiazol-2-il)-2,5-difeniltetrazólio
} 


\section{Introduction}

Nowadays MRI is becoming a common complementary diagnostic exam to acquire body images of great detail (Hornak, 2008; Risse, 2005). Despite being a theme of discussion within the scientific community about the effect of magnetic fields (e.g., cell phones, high voltage towers, magnetic resonance imaging), the effects of such technique are considered minimal. There are only a few studies about the possible implications of this methodology, with different kinds of cells and magnetic field intensities, but it is not even recognized as an exam that must be used with precaution (Aldinucci et al., 2003; Heine et al., 1999; Onodera et al., 2003; Papatheofanis, 1990; Raylman et al., 1996; Roman et al., 2005; Sakurai et al., 1999; Salerno et al., 2006; Schiffer et al., 2003; Stolfa et al., 2007; Valiron et al., 2005; Wiskirchen et al., 2000).

Macrophages derive from monocytes and can be found in every organ and in every tissue of the organism. According to the tissue they are located in, they can be divided into normal and inflammatory macrophages. Either resident or fixed, these specialized eukaryotic cells are crucial to the vertebrate immune system, as they play a very important defensive role by cleaning, through phagocytosis, pathogens, cancer cells and debris by membranous engulfment and internalization (Appelberg, 1999; Guyton and Hall, 2000). While studying macrophages in vitro, there are two main characteristics that must be considered: the first one is that they are adherent cells; the second one is that they almost do not divide when in culture, contrary to what happens in vivo. It is then more accurate to refer to the process as cell maintenance instead of cell culture (Appelberg, 1999).

There are several methods to determine cell viability and proliferation. Trypan blue is a very common test for evaluating cell viability. It is performed by adding the blue dye to the cells in a 1/1 concentration (Strober, 2001). To observe nondyed cells an inverted optical microscope is used. The common viable cells are those within which there is no dye. This means that the cell has an intact membrane and, as such, the dye cannot enter the cell. However, in dead cells, the dye crosses the membrane because it is disrupted. This is why the trypan blue method is also known as an exclusion method. Nevertheless, macrophages, when viable, have a blue coloration. This occurs because macrophages have phagocytic abilities and are able to transport foreign particles into their cytoplasm by endocytosis. As a result, active and viable macrophages will recognize the trypan blue dye as a foreign particle and will automatically phagocyte it. As such they will appear blue when observed at the optical microscope. Contrary to what happens in the other types of cells, for macrophages the bluish the better.

The most widely test to study cell viability and proliferation is the MTT (3-(4,5-dimethylthiazol-2-yl)-2,5-diphenyltetrazolium bromide) colorimetric assay (Molinari et al., 2005; Niu et al., 2001). It measures the mitochondrial and respiratory chain activity. When these mechanisms are intact, the enzyme succinate dehydrogenase is active and reduces the yellow tetrazolium to purple formazan crystals, which can be quantified photometrically after their solubilisation with an organic solvent in a multi-well scanning spectrophotometer (ELISA readers) at $570 \mathrm{~nm}$. Activated cells produce more formazan than non-activated ones, being its quantity directly proportional to the number of viable cells. For macrophages, which do not divide in vitro, this is especially important because it enables the evaluation of their responsiveness to external stimulus and the determination of the amplitude of such response, due to their metabolic rate.

It has been shown that cells undergoing apoptosis break up the phospholipid asymmetry of their membrane exposing phosphatidylserine (PS), which is translocated to the outer layer of the membrane. This transformation occurs in the early phases of apoptotic cell death, during which the cell membrane remains intact (Toms et al., 2005). Annexin V has proven to be a useful tool in detecting apoptotic cells since it preferentially binds to negatively charged phospholipids like PS in the presence of $\mathrm{Ca}^{2+}$ (Koopman et al., 1994). Changes in PS asymmetry are detected before morphological changes associated with apoptosis occur and before membrane integrity is lost. By conjugating FITC (fluorescein isothiocyanate) to Annexin V it is possible to identify and quantify apoptotic cells on a single-cell basis by flow cytometry. Propidium iodide (PI) binds to DNA by intercalating between the bases with little or no sequence preference (Strober, 2001). PI is membrane impermeant and it is generally excluded from viable cells. PI is commonly used for identifying dead cells in a population. Staining cells simultaneously with FITC-Annexin V (green fluorescence) and the non-vital dye propidium iodide (red fluorescence) allows the discrimination (bivariate analysis) of intact cells (FITC-PI-), early apoptotic (FITC+PI-) and late apoptotic or necrotic cells (FITC+PI+). Autofluorescence drop precedes the loss of cell viability, being higher in more complex and non-smooth cell surfaces.

In the present study, our goal was to try to find evidence of any possible effects on cellular viability 
of rat peritoneal macrophages exposed to MRI head and thorax standard exams with two different field intensities: 1.5 and $3 \mathrm{~T}$ along time $(\mathrm{t}=0-156 \mathrm{~h})$.

\section{Material and Methods}

\section{Macrophage isolation}

Peritoneal macrophages were harvested from Wistar rats (200 $\mathrm{g}$ of weight and 6-8 weeks of age, sacrificed by anæsthetic overdose), inside a laminar flow chamber. Throughout the procedure sterile material and PBS solution ( $\mathrm{pH}$ 7.2-7.4) were used, following the protocol implemented in the laboratory (Santos, 2001).

\section{Peritoneal macrophages in vitro}

The cells were divided into three groups (Control, Head and Thorax) in three 6 wells sterile flat bottom culture plates for each irradiation intensity. Cells were seeded in 2 of the wells of each plate at the concentration of $5 \times 10^{5}$ cells $/ \mathrm{mL}$ by well. Afterwards, the plates were incubated during $5 \mathrm{~h}$ at $37^{\circ} \mathrm{C}$ in an adequate incubator with a $5 \% \mathrm{CO}_{2}$ flow. Following this incubation period, the removal of the non-adherent cells was made through two washes with sterile PBS $(1 \mathrm{~mL} /$ well $)$ and then the cells were placed in a new aliquot of RPMI 1640 culture medium $(1 \mathrm{~mL} /$ well).

All materials and non-organic reagents were previously sterilized in an autoclave at $120^{\circ} \mathrm{C}$ during 20 min. The complete RPMI 1640 culture medium was prepared from sterile components but for extra security was resterilized by filtration with a sterile filter of porosity lower than $0.22 \mu \mathrm{m}$ (Santos, 2001).

\section{Magnetic resonance imaging}

Two days after isolation and culture, all the plates were sealed with scotch tape, and taken to the MRI hospital department $(1.5 \mathrm{~T})$ or the Imaging Brain Network Service (3 T), in aseptic and sterile conditions in a foam box, packed with cotton, foam and absorbent paper in order to maintain the optimal microenvironment. The Head plates were submitted to a typical head exam and the Thorax plates to a thorax protocol. The Control cells, although not exposed to a magnetic field, were kept in the same room, under the same conditions of the other groups. The exams were performed using the standard protocol sequences of the department (without contrast) in emergency cases. The experiment took $35 \mathrm{~min}$ and $14 \mathrm{sec}$ for the head sample and $12 \mathrm{~min}$ and $57 \mathrm{sec}$ for the thorax.

After exposure to the magnetic fields, the plates were put in the incubator for $1 \mathrm{~h}: 30 \mathrm{~min}$ to stabilize. Then, the cells were washed with sterile PBS and the adherent macrophages were detached from the 6 well plates using a cell scraper. Cells were resuspended in complete fresh RPMI 1640, centrifuged for $10 \mathrm{~min}$ at $1,100 \mathrm{rpm}$ at $4{ }^{\circ} \mathrm{C}$; resuspended again in fresh RPMI medium and counted with a Neubauer chamber after dilution $(1: 1)$ in trypan blue $0.4 \%$ in order to determine the cell concentration. Cell suspension was homogenized and cells were reseeded in sterile 96 well plates, since the microELISA only reads this kind of plates. A 96 well plate was prepared for each time of the experiment: $0,12,36,60,84,108$ and $132 \mathrm{~h}$ after exposure $\left(t_{0}-t_{6}\right)$. In each plate, cells were distributed in triplicates for each irradiation time (1.5 and $3 \mathrm{~T}$ ) for MTT and for FITC-Annexin V tests, respectively, in order to try to obtain significant results, for the three chosen conditions (Control, Head and Thorax).

Cell viability and response have been studied using two different tecnhiques: MTT colouring assay and flow cytometry (autofluorescence, propidium iodide, annexin $\mathrm{V}$, and morphological parameters), following the standard protocols.

\section{Results}

The MTT test results (Figure 1) enabled us to perform statistical analysis that shows significant differences between the three groups at $1.5 \mathrm{~T}(\mathrm{p}=0.003)$ and $3 \mathrm{~T}(\mathrm{p}=0.021)$ along time. The cells catalogued as Thorax also tried to react to the irradiation, however there are statistically significant differences between the Thorax cells at 1.5 and $3 \mathrm{~T}(\mathrm{p}=0.031)$ along time. Control cells progress normally.

By flow cytometry (Figures 2 and 3 ) it has been observed that a small percentage of cells $(<3 \%)$ are necrotic, however in some cases $(>12 \%)$ cells express Annexin V, meaning apoptosis.

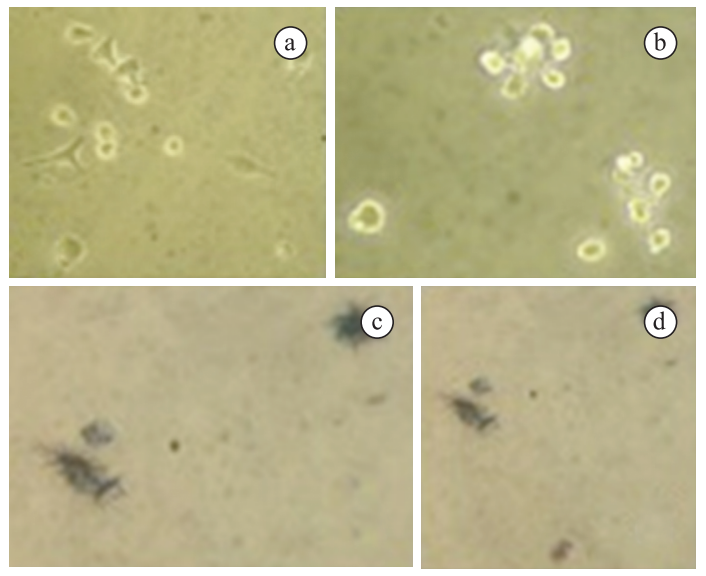

Figure 1. Microscopic visualization of macrophages (Head exam): a) pre-irradiation; b) immediately after; c) $\mathrm{t}_{5}$ post-irradiation $(84 \mathrm{~h})$; d) $\mathrm{t}_{7}$ post-irradiation $(132 \mathrm{~h})(400 \times)$. 


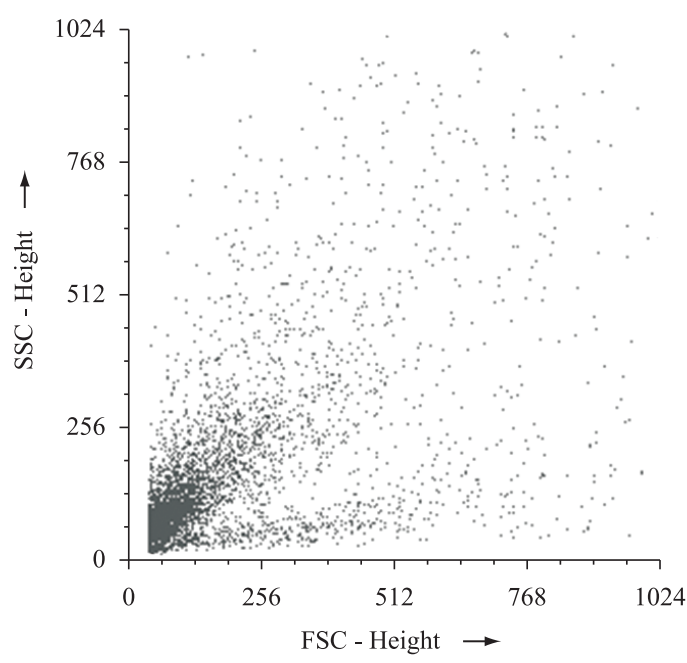

Figure 2. Flow cytometry dot plot [X axis: forward scatter (FSC); $\mathrm{Y}$ axis: side scatter (SSC)]. FSC correlates with cell size and SSC correlates with peripheral diversity of cell membranes.

\section{Discussion and Conclusions}

The MTT assay showed that both cells submitted to a Head or a Thorax MRI exam have a poor behaviour with both intensity fields, when comparing to the Control group, which progressed normally. The cells are more distressed by the Head exam conditions (for both intensity fields). At the end of our study, flow cytometry showed lower membrane permeability with fluidity loss for both irradiated cells. The cells presented high variability, which can influence the autofluorescence results.

Our findings lead to conclude that, in our experimental conditions, the MRI exams affected the rat peritoneal macrophages. It was also observed that the two different equipments used for irradiation had different effects on the cells' viability, correlating with the field intensity.

\section{References}

Aldinucci C, Garcia JB, Palmi M, Sgaragli G, Benocci A, Meini A, Pessina F, Rossi C, Bonechi C, Pessina GP. The effect of strong static magnetic field on lymphocytes. Bioelectromagnetics. 2003; 24(2):109-17. PMid:12524677. http://dx.doi.org/10.1002/bem.10071

Appelberg R. As células fagocíticas. In: Azevedo C. Biologia Celular e Molecular. 3th ed. Lisboa: Lidel; 1999. p. 416-27.

Crompton T, Peitsch MC, MacDonald HR, Tschopp J. Propidium iodide staining correlates with the extent of DNA degradation in isolated nuclei. Biochemical and Biophysical Research Communications. 1992; 183(2):532-37. http://dx.doi.org/10.1016/0006-291X(92)90514-L

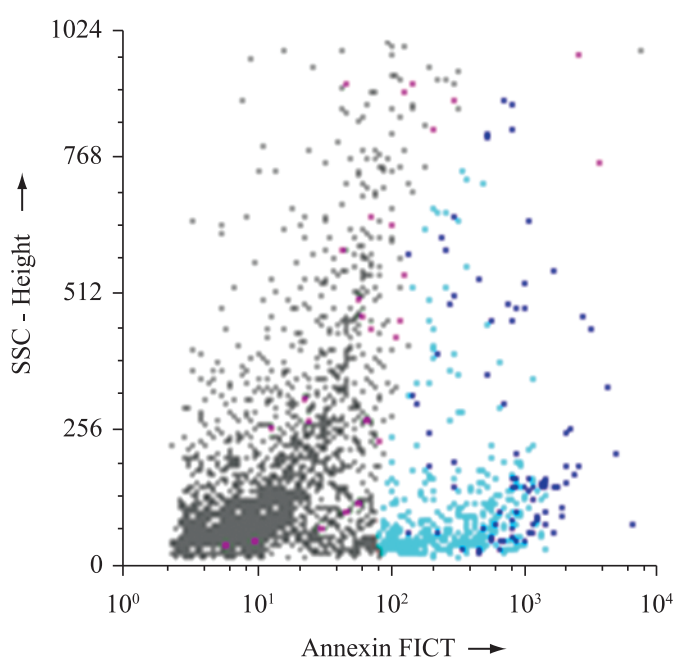

Figure 3. Flow cytometry dot plot [X axis: annexin FICT; $\mathrm{Y}$ axis: $\mathrm{SSC}$. Positive cells for annexin- $\mathrm{V}$ are colloured in red; yellow dots correspond to necrotic cells (positive for propidium iodide).

Guyton AC, Hall EH. Resistance of body to infection: I. leukocytes, granulocytes, the monocyte-macrophage system, and inflammation. In: Guyton AC, Hall EH. Textbook of medical physiology. 10th ed. Philadelphia: W. B. Saunders; 2000. p. 392-401.

Heine EJ, Scheinichen D, Jaeger K, Herzog T, Sümpelmann $\mathrm{R}$, Leuwer M. Effect of magnetic resonance imaging on human respiratory burst of neutrophils. FEBS Letters. 1999; 446(1):15-7. http://dx.doi.org/10.1016/S00145793(99)00183-0

Hornak JP. The Basics of MRI. [Internet]. [cited 2008 Dez. 06]. Available from: http://www.cis.rit.edu/htbooks/ mri/index.html

Koopman G, Reutelingsperger CP, Kuijten GAM, Keehnen RMJ, Pals ST, Van Oers MHJ. Annexin V for flow cytometric detection of phosphatidylserine expression on B cells undergoing apoptosis. Blood. 1994; 84(5):1415-20. PMid:8068938.

Molinari BL, Tasat DR, Palmieri MA, Cabrini RL. Kinetics of MTT-formazan exocytosis in phagocytic and non-phagocytic cells. Micron. 2005; 36(2):177-83. PMid:15629649. http://dx.doi.org/10.1016/j.micron.2004.08.002

Niu Q, Zhao C, Jing Z. An evaluation of the colorimetric assays based on enzymatic reactions used in the measurement of human natural cytotoxicity. Journal of Immunological Methods. 2001; 251(1-2):11-9. http://dx.doi.org/10.1016/ S0022-1759(01)00314-3

Onodera H, Jin Z, Chida S, Suzuki Y, Tago H, Itoyama Y. Effects of 10-T static magnetic field on human peripheral blood immune cells. Radiation Research. 2003; 159(6):775-9. http://dx.doi.org/10.1667/0033-7587(2003)159[0775:EOT $\mathrm{SMF}$ 2.0.CO;2

Papatheofanis FJ. Use of calcium channel antagonists as magnetoprotective agents. Radiation Research. 
1990; 122(1):24-8. PMid:2320722. http://dx.doi. org/10.2307/3577578

Raylman RR, Clavo AC, Wahl RL. Exposure to strong static magnetic field slows the growth of human cancer cells in vitro. Bioelectromagnetics. 1996; 17(5):358-63.

Risse J. Magnetic resonance imaging. In: Biersack HJ, Grünwald F. Thyroid cancer. 2th ed. New York: Springer; 2005. p. 251-54. http://dx.doi.org/10.1007/3-540-27845-1_15

Roman NA, Zyss T, Nalepa I. Magnetic field inhibits isolated lymphocytes' proliferative response to mitogen stimulation. Bioelectromagnetics. 2005; 26(3):201-6. PMid:15768428. http://dx.doi.org/10.1002/bem.20066

Sakurai, H, Okuno K, Kubo A, Nakamura K, Shoda M. Effect of a 7-tesla homogeneous magnetic field on mammalian cells. Bioelectrochemistry and Bioenergetics. 1999; 49(1):57-63.

Salerno S, La Mendola C, Lo Castro A, Mamone G, Caccamo N, Cardinale AE, Salerno A. Reversible effect of MR and ELF magnetic fields $(0.5 \mathrm{~T}$ and $0.5 \mathrm{mT})$ on human lymphocyte activation patterns. International Journal of Radiation Biology. 2006; 82(2):77-85.

Santos AC. Água trocável do pulmão: contribuição para o desenvolvimento de uma metodologia para a sua avaliação [tese]. Coimbra: Faculdade de Medicina da Universidade de Coimbra; 2001.

Schiffer IB, Schreiber WG, Graf R, Schreiber EM, Jung D, Rose DM, Hehn M, Gebhard S, Sagemüller J, Spiess $\mathrm{H}$, Oesch F, Thelen M, Hengstler JG. No influence of magnetic fields on cell cycle progression using conditions relevant for patients during MRI. Bioelectromagnetics. 2003; 24(4):241-50.

Stolfa S, Skorvánek M, Stolfa P, Rosocha J, Vasko G, Sabo J. Effects of static magnetic field and pulsed electromagnetic field on viability of human chondrocytes in vitro. Physiological Research. 2007; 56(1):S45-S9. PMid:17552895.

Strober W. APPENDIX 3B Trypan Blue Exclusion Test of Cell Viability. Current Protocols in Immunology. 2001. http://dx.doi.org/10.1002/0471142735.ima03bs21

Toms SA, Muhammad O, Jackson H, Lin WC. Decline in $\mathrm{NAD}(\mathrm{P}) \mathrm{H}$ autofluorescence precedes apoptotic cell death from chemotherapy. In: Analoui M, Dunn, DA. (Ed.). Optical methods in drug discovery and development. Proceedings of the SPIE. 2005; 6009:115-24. http://dx.doi. org/10.1117/12.630711

Valiron O, Peris L, Rikken G, Schweitzer A, Saoudi Y, Remy C, Job D. Cellular disorders induced by high magnetic fields. Journal of Magnetic Resonance Imaging. 2005; 22(3):334-40. PMid:16106367. http://dx.doi.org/10.1002/jmri.20398

Wiskirchen J, Grönewäller EF, Heinzelmann F, Kehlbach R, Rodegerdts E, Wittau M, Rodemann HP, Claussen CD, Duda SH. Human fetal lung fibroblasts: in vitro study of repetitive magnetic field exposure at $0.2,1.0$, and $1.5 \mathrm{~T}$. Radiology. 2000; 215:858-62. PMid:10831711.

\section{Authors \\ Ana Cristina Santos, Cláudia Matos, Bárbara Oliveiros, Filomena Botelho \\ Instituto de Biofísica e Biomatemática - IBILI, Faculdade de Medicina da Universidade de Coimbra - FMUC, Universidade de Coimbra, Coimbra, Portugal}

Ana Rita Bento, Eliana Murteira, Filipe Leite, Marco Pinto, Micaela Cunha, Rosalindo Gomes

Departamento, Faculdade de Ciências e Tecnologia, Universidade de Coimbra, Coimbra, Portugal

Alda Martins, Filipe Caseiro Alves

Serviços de Imagiologia, Hospitais da Universidade de Coimbra, Coimbra, Portugal

\section{Carlos Ferreira, Miguel Castelo-Branco}

Rede Nacional de Imagiologia Funcional Cerebral, Instituto de Biofísica e Biomatemática - IBILI,

Faculdade de Medicina da Universidade de Coimbra - FMUC, Universidade de Coimbra, Coimbra, Portugal

\section{Vera Alves, Manuel Santos-Rosa}

Instituto de Imunologia, Faculdade de Medicina da Universidade de Coimbra - FMUC, Universidade de Coimbra, Coimbra, Portugal 